\title{
O TRATAMENTO DUAL DOS CRIMES POLÍTICOS NO CONTEXTO DOS DIREITOS HUMANOS
}

\section{THE DUAL TREATMENT OF POLITICAL OFFENSES WITHIN THE FRAMEWORK OF HUMAN RIGHTS}

\section{RESUMO}

\author{
${ }^{1}$ Daniela Silva Fontoura de Barcellos \\ ${ }^{2}$ Paulo Emílio Vauthier Borges De Macedo
}

\begin{abstract}
A expressão crime político designa genericamente todo o ato atentatório contra a ordem pública interna ou externa e contra a segurança nacional. No entanto, há um duplo tratamento para essa conduta no ordenamento brasileiro. De um lado, a expressão foi utilizada especialmente durante a época dos regimes autoritários brasileiros para designar toda a atividade contra a ordem pública e a segurança nacional. Nestes casos, a qualificação de crime político serviu de justificativa para a perda de direitos e garantias processuais, como a proibição do habeas corpus, o julgamento de civis por militares e o agravamento de penas. De outro, a caracterização de um crime como político pode obstar a extradição de estrangeiros e lhes conceder a possibilidade de obter asilo no país, o que impede a atividade persecutória penal do outro Estado. Assim, o presente artigo tem por objetivo demonstrar essa duplicidade de tratamento dos crimes políticos no direito brasileiro, bem como os critérios utilizados para a sua categorização. A metodologia utilizada consiste numa análise histórica do conceito mencionado e apresenta o estado da arte quanto aos seus usos no Brasil contemporâneo. Para a realização dos nossos objetivos, utilizamos como fontes as normas nacionais e internacionais que versam sobre a categoria de crime político e a sua interpretação jurisprudencial desde a Era Vargas até o período atual, tendo como base empírica os julgados do Supremo Tribunal Federal.
\end{abstract}

Palavras-chave: Direitos humanos, Crime político, Lei de segurança nacional, Extradição

\begin{abstract}
In general, the expression political offense means every harmful act against the domestic or international public order and against national security. However, there is a double treatment for this behavior in the Brazilian system. On one hand, the expression was used especially during the era of Brazilian authoritarian regimes to designate any activity against the public order policy and national security. In these cases, the political nature of the offense served to justify the loss of rights and guarantees, such as the prohibition of habeas corpus, the trial of civilians by military personnel and the aggravation of penalties. On the other, the characterization of a crime as a political may prevent the extradition of foreigners by granting them the possibility of obtaining asylum in the country, which hinders the criminal persecution action from the other State. Hence, this paper aims to demonstrate this duplicity of treatment of political offenses in Brazilian law, as well as the criteria used for this categorization. The methodology consists of a historical analysis of the aforementioned concept and presents the current state of the art as to its uses in Brazil. In order to achieve our purposes, we have employed as sources the national and international norms that display the category political offense and their empiric interpretation in the rulings of the Brazilian Supreme Court, since the Vargas Era until today.
\end{abstract}

Keywords: Human rights, Political offenses, National security law, Extradiction

\footnotetext{
${ }^{1}$ Doutora em Ciência Política pela Universidade Federal do Rio Grande do Sul - UFRGS, Porto Alegre, (Brasil). Professora Adjunta de Direito Civil da Faculdade Nacional de Direito da UFRJ, Brasil. E-mail: tutortreinamento@gmail.com

${ }^{2}$ Doutora em Direito pela Universidade do Estado do Rio de Janeiro - CEPUERJ, (Brasil). Professor Adjunto da Universidade Federal do Rio de Janeiro - UFRJ, e da Universidade do Estado do Rio de Janeiro, CEPUERJ. Email: tutortreinamento@gmail.com
} 


\section{INTRODUÇÃO}

A expressão "crime político" não possui definição uniforme na doutrina jurídica. Grosso modo, pode dizer-se que ela designa um gênero de todos os atos atentatórios contra a ordem pública interna ou externa e contra a segurança nacional. No entanto, a legislação nacional e os compromissos internacionais do Brasil apresentam tratamento diferenciado e, por vezes, até mesmo oposto para esta mesma situação jurídica.

A nomenclatura foi utilizada especialmente durante a época dos regimes autoritários brasileiros - incluindo a Era Vargas e o Governo Militar - para designar toda a atividade considerada nociva ao regime, à ordem pública e à segurança nacional. Neste caso, a qualificação de crime político serviu de justificativa para a perda de direitos e garantias processuais, como a proibição de habeas corpus $^{l}$, o julgamento de civis por militares e o agravamento de penas. Possibilitava, pois, instaurar a persecução penal àquelas pessoas que haviam cometido condutas tidas como "subversivas". Como será visto depois, durante o Regime Militar, especialmente com a publicação do AI-5, os crimes políticos sofreram a suspensão do direito ao habeas corpus (art. 10 do AI-5).

Todavia, quando dirigida a uma conduta praticada fora do Brasil, a caracterização de crime político pode obstar a extradição de estrangeiro e, até mesmo, possibilitar-lhe a obtenção de asilo ou refúgio no país, o que permite frustrar a persecução criminal do Estado estrangeiro. Eis o paradoxo: essa qualificação serve para possibilitar uma punição mais severa internamente e, ao mesmo tempo, impedir um país estrangeiro de satisfazer a sua jurisdição punitiva.

Assim, o presente artigo tem por objetivo demonstrar a duplicidade de tratamento do delito político no direito brasileiro, bem como os critérios utilizados para sua categorização. A metodologia consiste na apresentação do estado da $\operatorname{arte}^{2}$ dessa noção no Brasil contemporâneo. Para a realização dos nossos objetivos, utilizamos como fontes a legislação nacional e a interpretação jurisprudencial atinentes ao crime político desde a

\footnotetext{
${ }^{1}$ Habeas corpus é a medida judicial para evitar e cessar detenção ou prisão ilegal. Ficou suspenso no Brasil durante parte da Era Vargas e, no período da ditadura civil-militar, de 13 de dezembro de 1968 a 17 de outubro de 1978 para alguns tipos de crimes, especialmente crimes contra a segurança nacional, crimes políticos e crimes eleitorais.

${ }^{2}$ As pesquisas de estado da arte ou estado do conhecimento são definidas como sendo predominantemente de caráter bibliográfico, tendo em comum o desafio de mapear e de discutir certa produção acadêmica em determinado campos do conhecimento. (FERREIRA, Norma Sandra de Almeida. As pesquisas denominadas "estado da arte". Educação \& Sociedade, 2002, Vol. 23, p. 257-272).
} 
Era Vargas até o período atual, tendo sempre como base empírica os julgados do Supremo Tribunal Federal.

Nosso plano de exposição, divide-se em duas partes. Na primeira, abordaremos como o direito nacional vem caracterizando o crime político para fins de extradição. $\mathrm{Na}$ segunda, analisaremos, como o direito brasileiro empregou a expressão para fins de aplicação de tratamento mais severo, presentes especialmente na Lei de Segurança Nacional e, posteriormente, ao ampliar ainda mais a sua abrangência para possibilitar a obtenção de anistia.

\section{CRIME POLÍTICO E EXTRADIÇÃO}

Seguindo uma tendência mundial, a atual Constituição Brasileira (art. $5^{\circ}$, LII) e o Estatuto do Estrangeiro (Lei n. 6815/1980, art. 77, VII) vedam a extradição de pessoa que tenha cometido crime político. Esta regra já se encontrava nos ordenamentos brasileiros anteriores, plasmado nas constituições de 1934 (art. 113. n. 31), 1946 (art. 141, §33) e de 1967-69 (art. 150, §19 e art. 153, §19). Segundo Oscar Tenório, o princípio da não extradição de criminoso político fundamenta-se "na própria necessidade de defesa da personalidade humana contra o arbítrio e o ódio que surgem em tempos de exaltação"3.

Porém, nem sempre isso foi assim. Até o século XIX, a extradição era uma forma de cooperação política entre soberanos, estabelecida por regras não propriamente jurídicas, mas de comitas gentium. A distinção entre crimes políticos e comuns não fazia sentido. Em si, os crimes políticos consistem em comportamentos tão nocivos ou mesmo mais graves dos que os crimes comuns. ${ }^{4}$ Ademais, o país que abrigar um criminoso político pode colocar a sua própria segurança em risco, ao se tornar um centro de convergência para atividades subversivas. ${ }^{5}$

A partir do século XIX, por influência da doutrina liberal, passam a ser introduzidos dois institutos assecuratórios da dissidência política nas normas de

\footnotetext{
3 TENÓRIO, Oscar. Direito Internacional Privado. 11 ed. Rio de Janeiro: Freitas Bastos, 1976, v. II, p. 403.

${ }^{4}$ ACCIOLY, Hildebrando. Manual de Direito Internacional Público. 6. ed. São Paulo: Saraiva: 1964, p. 117.

${ }^{5}$ RUSSOMANO, Gilda Maciel Corrêa Meyer. A Extradição no Direito Internacional e no Direito Brasileiro. 3. ed. São Paulo: Revista dos Tribunais, 1981, p. 84.
} 
cooperação jurisdicional penal internacional: o asilo político e a proibição da extradição ao criminoso político. Nos tratados da Paz de Amiens de 1802, não se impôs mais a saída compulsória dos estrangeiros que tinham cometido um crime político. Em 1833, na lei belga sobre a condição jurídica dos estrangeiros, passou-se a proibir a saída compulsória do criminoso político. ${ }^{6}$ Logo depois, a França promoveu a mesma alteração legislativa, e essa vedação se espalhou pelos demais países europeus e americanos. Consoante Barroso e Tibúrcio, isso se deveu ao fato de que, após as revoluções burguesas, não teria havido mais uniformidade ideológica no cenário político internacional, o que fez determinadas posições poderem contar com a simpatia de alguns Estados - com a exceção talvez do movimento anarquista, que era considerado radical demais, pois ameaçava destruir todas as formas de governo, não somente uma em especial ${ }^{7}$.

Essa nova concepção se justificava por algumas razões bastante atraentes à ideia de liberdade da primeira metade do século XIX. O criminoso político seria considerado assim apenas porque fora um perdedor, um vencido político, alguém cujo crime foi se opor a uma determinada ordem estabelecida. ${ }^{8}$ Isso implica afirmar que o caráter delituoso dessa conduta é relativo, um Estado "pode punir um fato que, em outro país, pode ser admitido como prova de civismo, variando o critério de Estado para Estado, de acordo com as respectivas instituições ou com os respectivos costumes políticos" ". Portanto, estaria em perigo a imparcialidade do julgamento desse estrangeiro pelos tribunais do país em que ele cometeu o delito político.

O fato é que, em fins do século XIX, a proibição da extradição do criminoso político já se apresentava tão sedimentada no Direito Internacional Costumeiro que o Instituto de Direito Internacional (IDI) a consagrou nos arts. 13 e 14 das Resoluções de Oxford sobre Extradição de 1880. Doze anos depois, em Genebra, o IDI proclamou nova resolução regulamentando os dois artigos. Esta nova norma refletia a disposição padrão até hoje sobre a matéria em quatro artigos. Primeiro, a extradição não poderia ser concedida para crimes puramente políticos. Segundo, também não poderia ser admitida para crimes mistos ou infrações comuns conexas a crimes políticos, a menos que se comprovasse a preponderância da criminalidade comum desses delitos. Terceiro, em

\footnotetext{
${ }^{6}$ GOMES, Érica Xavier Moura. A Extradição e o Crime Político. Monografia de Conclusão de Curso de Direito. Rio de Janeiro: UFRJ, 2010, p. 53.

${ }^{7}$ BARROSO, Luís Roberto; TIBÚRCIO, Carmen. Direito Constitucional Internacional. Rio de Janeiro: Renovar, 2013, p. 335.

${ }^{8}$ GORAIEB, Elizabeth. A Extradição no Direito Brasileiro. Rio de Janeiro: Mauad, 1981, p. 72.

${ }^{9}$ ACCIOLY, Hildebrando. Op. Cit., p. 118.
} 
relação aos atos praticados no curso de uma insurreição ou guerra civil, a extradição só poderia ocorrer depois de terminado o conflito e apenas para aquelas condutas de "barbárie odiosa e vandalismo proibidos pelas leis da guerra". E, por fim, não constituiriam crimes políticos os fatos delituosos dirigidos contra as bases de toda organização social, não só contra um Estado ou uma forma de governo determinados. ${ }^{10}$

Nenhum tratado de extradição poderia dispor diferente. O Código Bustamante consagrou a exceção em seu art. $355^{11}$. Em 1944, o famoso internacionalista Hersch Lauterpacht afirmou que "na legislação dos países modernos, existem poucos princípios tão universalmente adotados como o da não extradição dos criminosos políticos" ${ }^{\prime 2}$.

\subsection{A Fluidez da Caracterização de um Delito como Político}

O problema sempre foi a distinção em concreto entre o crime político e o comum. No Brasil, é da competência exclusiva do STF caracterizar um crime como político (art. 77, §2º Lei n. 6.815/1980). Poderá inclusive retirar essa qualificação em atentados contra chefes de Estado ou quaisquer outras autoridades, bem como em atos de "anarquismo, terrorismo, sabotagem, sequestro de pessoa, ou que importem propaganda de guerra ou de processos violentos para subverter a ordem política ou social” (art. 77, §3º, Lei n.

6.815/1980), o que concede uma ampla margem de discricionariedade a esse órgão.

Entre os doutrinadores, as teorias objetivistas definem o crime político conforme o bem jurídico lesado. Assim, aqueles comportamentos que atentam contra a existência do Estado, ou de sua organização político-jurídica, poderiam enquadrar-se nessa definição. Já as teorias subjetivistas privilegiam a motivação do autor. Desse modo, não importaria qual o tipo penal foi descumprido; desde que o agente procurasse desestabilizar o regime político vigente, haveria um crime político. Atualmente, os ordenamentos nacionais aceitam mais as teorias mistas, que combinam os elementos objetivos e subjetivos. As teorias mistas podem ser extensivas ou restritivas: aquelas

\footnotetext{
${ }^{10}$ INSTITUT DE DROIT INTERNATIONAL.Justitiaet Pace. Résolutionsd'Oxford (Extradition). Session d'Oxford, 9 Septembre 1880. Rapporteurs MM. Ludwig von Bar, Charles Brocher, Louis Renault et Caspar Bluntschli e Révision des articles 13 et 14 des Résolutionsd'Oxford (Extradition). Session de Genève, 8 Septembre 1892. Rapporteurs MM. Albéric Rolin et Heinrich Lammasch. Disponível em <http://www.idi-iil.org/>, acesso em agosto de 2015.

11 "Estão excluídos da extradição os delitos políticos e com eles relacionados, segundo a definição do Estado requerido."

12، (...) in the legislation of modern states there are few principles so universally adopted as that of nonextradition of political offenders". (LAUTERPACHT, Hersch. Laws of nations and the punishment of war crimes. British Yearbook of International Law, n. 58, 1944).
} 
caracterizam como político os atentados contra a organização política de um Estado, além de todo ato com uma motivação política, e as últimas defendem a ideia de que constituem crimes políticos somente aquelas condutas que lesionam a existência constitucional do país e também apresentam fins políticos. Neste caso, excluem-se da definição tanto os crimes que, com o ânimo do lucro, ferem a ordem política do Estado como as infrações penais comuns (sequestro ou roubo) praticadas com um intento político. ${ }^{13}$

Outra classificação bastante empregada é aquela que divide os crimes políticos em delitos políticos puros, delitos políticos conexos a crimes de natureza comum e delitos políticos complexos. Os primeiros seriam aqueles que, sem o emprego da violência, a natureza política do ato resta bem caracterizada, pois se volta contra a organização política de um governo. É o caso clássico dos crimes de opinião contra um Estado autoritário. Nos delitos políticos conexos, existem simultaneamente duas infrações: uma política e outro comum, atrelados por conexão. E os crimes políticos complexos seriam aqueles que, por meio de um único ato, lesionam a ordem política e o direito penal comum. ${ }^{14} \mathrm{Com}$ base nestas distinções, os países adotam diferentes sistemas quando há o perpetuamento de um crime político relativo (conexo ou complexo) ${ }^{15}$ :

a) Sistema da separação: prevê que, nos casos de conexão, a extradição deve ser concedida para o crime comum e afastada para o delito político. Assim, em última análise, haverá a extradição, embora o pedido do Estado estrangeiro tenha sido apenas parcialmente deferido. O problema neste caso é a possibilidade sempre presente de arbitrariedade na sua aplicação, pois o extraditado corre o risco de ser julgado, ainda que de forma velada, pelo crime político;

b) Sistema do motivo determinante: dispõe a necessidade de sempre conjugar a motivação do agente com a finalidade pretendida. Este sistema abre para o critério subjetivista;

c) Sistema da causalidade: concede a extradição somente para os crimes políticos relativos que surgirem de uma insurreição ou forem consequência de motins. Embora haja uma restrição inicial (somente os delitos que ocorrem a partir de um golpe ou revolução), este sistema abre o espectro para uma gama muito ampla de condutas, todos legitimados pelo fato inicial.

\footnotetext{
${ }^{13}$ GUIMARÃes, Marcelo Ovídio Lopes. Tratamento Penal do Terrorismo. São Paulo: Quartier Latin, 2007. pp. 63-64.

14 ARAÚJO, Luiz Alberto David; PRADO, Luiz Régis. Alguns Aspectos das Limitações ao Direito de Extraditar. Revista de Informação Legislativa, Brasília, v. 19, n. 76, outubro/dezembro 1992, p. 79. Disponível em <http://www2.senado.gov.br/bdsf/item/id/181392>. Acesso em agosto 2015.

${ }^{15}$ RUSSOMANO, Gilda Maciel Corrêa Meyer. Op. Cit., pp. 91-92.
} 
d) Sistema da predominância: estabelece a necessidade de examinar cada caso em concreto para averiguar qual o delito que predomina. Isso significa dizer que ora o órgão julgador adota critérios mais objetivistas, ora mais subjetivistas.

Este sistema foi previsto no art. 77, $\S 1^{\circ}$, do Estatuto do Estrangeiro, in verbis: “A exceção do item VII [não conceder extradição por crime político] não impedirá a extradição quando o fato constituir, principalmente, infração da lei penal comum, ou quando o crime comum, conexo ao delito político, constituir o fato principal. (...)" $\mathrm{O}$ Supremo Tribunal Federal consagra este sistema em diversos julgados. Por exemplo:

EXTRADIÇÃO EXECUTÓRIA. NATUREZA DO PROCESSO EXTRADICIONAL. LIMITAÇÃO AO PODER JURISDICIONAL DO STF. TRIBUNAL DE EXCEÇÃO. CRIME POLÍTICO RELATIVO. PRESCRIÇÃO DA AÇÃO. Processo de extradição, no exame do pedido extradicional o STF ater-se-á à legalidade da pretensão formulada. (...) Crime político. Exame da sua configuração, como exceção impeditiva da concessão da extradição, deferida exclusivamente ao STF. Crime complexo ou crime político relativo, critério para a sua caracterização assentado na predominância da infração penal comum sobre aquelas de natureza política. Art. 77, pars.

1 e 2 da Lei 6815/80. Não havendo a constituição definido o crime político, ao Supremo cabe, em face da conceituação da legislação ordinária vigente, dizer se os delitos pelos quais se pede a extradição constituem infração de natureza política ou não, tendo em vista o sistema da principalidade ou da preponderância $(. . .)^{16}$. (grifo nosso)

Barroso e Tibúrcio criticam este art. $77, \S 1^{\circ}$, da Constituição Federal porque a norma constitucional que veda a extradição não prevê qualquer ressalva ou limitação. Assim, a legislação ordinária não poderia impor uma restrição a uma garantia constitucional $^{17}$.

Outro limite à não extradição do crime político se encontra prevista na primeira parte do art. $77, \S 3^{\circ}$ : “O Supremo Tribunal Federal poderá deixar de considerar crimes políticos os atentados contra Chefes de Estado ou quaisquer autoridades, bem assim os atos de anarquismo, terrorismo, sabotagem, sequestro de pessoa, ou que importem propaganda de guerra ou de processos violentos para subverter a ordem política ou social” (grifo nosso). Esta exceção é conhecida como "cláusula do atentado" ou “cláusula belga". Ela remonta a um atentado contra Napoleão III, o qual não foi julgado

\footnotetext{
${ }^{16}$ BRASIL. Supremo Tribunal Federal. (Tribunal Pleno). Extradição n. 615. Governo da Bolívia e Luís Garcia Meza Tejada. Rel. Min. Paulo Brossard. J. em 19/10/1994.

${ }^{17}$ BARROSO, Luís Roberto; TIBÚRCIO, Carmen. Op. Cit., p. 344.
} 
porque o agente se refugiou na Bélgica, que não deferiu a extradição por considerar o fato delituoso de natureza política. Como reação à decisão do Judiciário, o Legislativo belga aprovou em 1856 uma lei que proibiu atribuir a qualificação de político a um atentado a um chefe de Estado estrangeiro, ou a membro da sua família. ${ }^{18}$

Essa cláusula tem os seus defensores e os seus detratores. A ideia por trás dela é a de que deveria haver um limite à violência feita pelo dissidente político em sua oposição ao governo, e esse limite deveria ser o assassinato do chefe de Estado. Entretanto, por que a vida de uma autoridade mereceria tratamento diferenciado? A vida do chefe de Estado é tão importante como a vida dos cidadãos comuns. Cumpre salientar que o Estatuto do Estrangeiro não obriga nem proíbe a cláusula belga; ela consiste numa faculdade.

\subsection{Mais Fluidez Conceitual: Terrorismo e os Crimes de lesa Humanidade}

Quanto ao restante do art. 77, $\S 3^{\circ}$, da Carta Magna há uma tendência bastante significativa de subtrair do beneplácito da não extradição as condutas anarquistas, terroristas e de lesa humanidade, entre outras. Assim como na cláusula belga, a razão de ser dessas exclusões seria a de introduzir algum limite à violência que o dissidente político poderia promover. Diversos tratados dos quais o Brasil faz parte consagram esta noção. $\mathrm{O}$ Acordo de Extradição entre os Estados Partes do Mercosul de 1998 prevê, num rol bastante extenso e não exaustivo do seu art. $5^{\circ}, \S 2^{\circ}$, as ações de genocídio, crimes de guerra, crimes contra a humanidade, terrorismo, atentados a pessoas internacionalmente protegidas, sequestro, atentados com o emprego de bombas e explosivos, captura e embarcações e aeronaves, além de atos contra a economia de um Estado e o seu patrimônio cultural e ecológico. A Convenção Interamericana Contra o Terrorismo de 2002 dispõe, no seu art. 11, a “inaplicabilidade da exceção do delito político”:

Para os objetivos de extradição ou mútua assistência jurídica, nenhum dos delitos estabelecidos nos instrumentos internacionais listados no Artigo $2^{\circ}$ deverá ser considerado delito político, ou delito conexo a um delito político ou um delito inspirado por motivos políticos. Em consequência, uma solicitação de extradição ou de assistência jurídica mútua não poderá ser denegada somente com base em que se relaciona com um delito político, ou com um delito conexo a um delito político ou com um delito inspirado por motivos políticos.

\footnotetext{
${ }^{18}$ GOMES, Érica Xavier Moura. Op. Cit., p. 61.
} 
Como afirmado, o motivo dessa disposição é o de impor limites à violência. $\mathrm{Na}$ Extradição n. 417/1984, o pedido formulado pela República Argentina foi deferido, e a essência política do delito afastada. Em seu voto, o Ministro Oscar Corrêa afirmou que, em vista da gravidade e da extensão das ações praticadas por Mário Eduardo Firmenich, como uma das lideranças do grupo subversivo dos Montoneros, não se pode considerar o seu comportamento um crime político ${ }^{19}$. Deve ressaltar-se que, à época dos atos delituosos do extraditando, a Argentina passava por um regime de exceção, o que contraria a tese de que $a b$ initio todos os atos praticados contra um regime ditatorial seriam crimes políticos sempre.

Cabe observar que em relação aos crimes de lesa humanidade, o Estatuto de Roma, que criou o Tribunal Penal Internacional, conferiu maior precisão. Porém, no que se refere ao terrorismo, a situação se apresenta bastante precária. Se aqueles sistemas e critérios vistos anteriormente conseguem diferenciar o crime político do comum com pouca previsibilidade, eles nada têm a dizer no que se refere ao terrorismo. Segundo Luís Jiménez de Asúa,

los delitos terroristas, o más brevemente el terrorismo, como se acostumbra designarlos en los Congresos y Conferencias internacionales, no constituyen una figura homogénea ni caracterizada por fines altruistas ulteriores, sino por el medio ocasionado a grandes estragos, por la víctima, que puede ser un magnate o personaje, o, en contrapartida, personas desconocidas que accidentalmente se hallan en medios de transporte, plazas, calles, etc., y por el inmediato fin de causar intimidación pública. ${ }^{20}$

Ora, também o crime político visa causar intimidação pública. Ademais, o caráter altruísta de um atentado terrorista pode ser medido pelo fato de que o agente se encontra disposto a sacrificar sua própria vida pela causa.

Para Luiz Régis Prado, os tipos penais praticados por um agente terrorista “obedecem a um plano cuidadosamente organizado, dirigido para a consecução de um objetivo que transcende a finalidade intrínseca de cada uma das condutas delitivas

\footnotetext{
${ }^{19}$ Voto do Ministro Oscar Corrêa. In: BRASIL. Supremo Tribunal Federal (Tribunal Pleno). Extradição n. 417. República Argentina e Mário Eduardo Firmenich. Relator Ministro Alfredo Buzaid. j. 20 de maio de 1984. p. 54-59.

${ }^{20}$ JIMÉNEZ DE ASÚA, Luis. Tratado de Derecho Penal. 5. ed. Buenos Aires: Editorial Losada, s/a. t. III. p. 185.
} 
individualmente consideradas ${ }^{21}$ ". Esta explicação, porém, não basta porque só corrobora o entendimento de que, tal como o crime político, o terrorismo não se exaure nos comportamentos criminosos devidamente tipificados: há um plano maior, o de desequilibrar a ordem vigente.

De acordo com outro doutrinador, o terrorismo, "ao contrário do crime político, se afasta do motivo efetiva e exclusivamente político e da ação dirigida contra a ordem política, já que seu propósito é o de ocasionar o terror, a intimidação ${ }^{22}$ ". A diferença, então, parece resumir-se a uma questão de escala: quando o ato não assusta ninguém, trata-se de delito político.

Um pouco adiante, o mesmo autor aponta outra diferença: o terrorismo "tende à destruição do regime político, social e econômico dos países, enquanto o delito político atinge a ordem política, dirigindo-se a um determinado Estado"23. Mais uma vez, reduzse a distinção a um problema de escala: se atinge um só país, é um crime político, mas, se ataca dois ou mais, então é um atentado terrorista.

Na Extradição n. 855/2004, o relator distingue uma figura da outra pelo fato de que o "terrorismo constitui um atentado às próprias instituições democráticas". Esse fundamento revela-se bastante precário. Desta feita, se o ato se dirigir contra um regime democrático, será terrorismo, mas, mutatis mutandi, se ele se opuser a um governo ditatorial, então será um crime político. Segundo este raciocínio, não há, pois, possibilidade de haver atentados terroristas a ditaduras, assim como não pode haver crimes políticos numa democracia, o que não prevaleceu na Extradição n. 417 de vinte anos antes. $^{24}$

Em seu voto no processo referido, o Ministro Sepúlveda Pertence ressalta a fluidez da definição de terrorismo: numa circunstância constitucional, um ato pode ser

\footnotetext{
${ }^{21}$ PRADO, Luiz Régis; CARVALHO, Érika. Delito Político e Terrorismo: uma aproximação conceitual. Revista dos Tribunais, n. 771, Doutrina Penal, Primeira Seção, janeiro de 2007, p. 437.

${ }^{22}$ GUIMARÃES, Marcelo Ovídio Lopes. Tratamento Penal do Terrorismo. São Paulo: Quartier Latin, 2007, p. 69.

${ }^{23}$ Ibidem, p. 69.

${ }^{24}$ No famoso Caso Battisti (BRASIL. Supremo Tribunal Federal. [Tribunal Pleno]. Extradição n. 1085. Governo da Itália e Cesare Battisti. Rel. Min. Cezar Peluso. J. 16 dezembro 2009), o STF afastou a qualificação de político aos crimes praticados pelo italiano por causa da sua extrema gravidade e pelo fato de terem ocorrido durante o funcionamento regular de um Estado de Direito! Este foi um caso bastante polêmico, sobre o qual se verteu rios de tinta, que abre para questões muito interessantes como a natureza jurídica do ato do Presidente de não executar a decisão da fase judicial da extradição, a diferença entre os institutos do asilo e do refúgio e a possibilidade, prevista na letra da Lei n. 9474/1997, da concessão do refúgio poder obstar o processo de extradição perante o STF (o que não ocorre com a concessão do asilo). No entanto, para os efeitos da presente pesquisa, este caso interessa como mais um exemplo da aplicação casuística do STF da qualificação de delito político.
} 
qualificado de terrorista, noutra, a mesma ação demanda outro tratamento. Num regime muito rígido, que impeça a manifestação da oposição, parece não restar aos opositores outra alternativa à violência, ao terror. Conclui o ministro que o STF deve formular juízos casuístas. Já o Ministro Nelson Jobim afirma que "terrorismo" não corresponde a um conceito que traduza um ato de realidade, mas um juízo de valor, que deve ser examinado caso a caso. Acrescenta que prefere, "intuitivamente", emitir um parecer em cima do caso e que renuncia "a qualquer possibilidade de discutir academicamente a busca de algo no mundo que seja terrorismo, o que não vai haver nunca. Isso depende do lado do muro em que se encontra." 25

Cumpre salientar que, em princípio, nenhum Estado admite a existência de delitos políticos em sua ordem jurídica - ou não deveria admitir, pois esta afirmação será relativizada a seguir. Diante do caso concreto, um país irá procurar desqualificar o crime político para comum. Como bem mencionou o Ministro Rezek, a "detecção do crime político só se faz de fora para dentro, só se faz à luz dos olhos do observador neutro" 26 . Com a previsão da impossibilidade de extradição para atentados terroristas, abre-se a oportunidade de sequer procurar descaracterizar-se a natureza política do ato; basta classificá-lo como "terrorismo" para que crimes políticos de grande repercussão possam ser julgados sem qualquer beneplácito.

\section{CRIME POLÍTICO E SEGURANÇA NACIONAL}

Paradoxalmente, desde a criação da Lei de Segurança Nacional ${ }^{27}$, durante a Era Vargas, as condutas contrárias ao regime, à segurança e à ordem pública nacional foram qualificadas de crimes políticos. A finalidade basilar de tal reconhecimento era agravar as penas, possibilitar o julgamento pelos rigorosos procedimentos das leis de segurança nacional que passaram a dar atenção ao "inimigo interno" praticante de atos tidos como

\footnotetext{
${ }^{25}$ Voto dos Ministros Sepúlveda Pertence e Nelson Jobim. In: BRASIL. Supremo Tribunal Federal (Tribunal Pleno). Extradição n. 855. República do Chile e Mauricio Hernandez Norambuena. Relator Ministro Celso de Mello. j. 26 de agosto de 2004. pp. 77-88. Atente-se ao fato de que a data dessa decisão é posterior a 1989.

${ }^{26}$ Voto do Ministro Francisco Rezek. In: BRASIL. Supremo Tribunal Federal (Tribunal Pleno). Extradição n. 417. República Argentina e Mário Eduardo Firmenich. Relator Ministro Alfredo Buzaid. j. 20 de maio de 1984. p. 49.

${ }^{27}$ Lei n. 38, promulgada em 4 de abril de 1935.
} 
subversivos e capazes de romper a ordem pública. No regime militar, houve o aumento das penas, a perda de direitos processuais, bem como a diminuição das garantias constitucionais atinentes à vida e à liberdade, com a instituição da pena de morte, da prisão perpétua e com a suspensão do habeas corpus.

No processo de abertura política, e durante o procedimento de negociação da anistia, o conceito de crime político foi ampliado para ter como agente não apenas os civis e militares que realizaram atos de resistência contra o governo, mas também passaram a abarcar os agentes do Estado que agiam como defensores do regime. É o que veremos a seguir na primeira e segunda partes desta seção.

\subsection{O Reconhecimento do "Ato Subversivo"como Crime Político}

A primeira Lei de Segurança Nacional, Lei n. 38, de 4 de abril de 1935 em sua ementa "define crimes contra a ordem política e social" (grifo nosso). A sua principal característica foi transferir para uma legislação especial os crimes contra a segurança do Estado, submetendo-os a um regime mais rigoroso, com o abandono de certas garantias processuais, além de possibilitar o agravamento das penas em relação aos crimes comuns. Nos anos seguintes à promulgação da Lei de Segurança Nacional, o governo Vargas, tornou esta lei ainda mais rigorosa e detalhada. Em setembro de 1936, a sua aplicação foi reforçada com a criação do Tribunal de Segurança Nacional, destinado especialmente para julgar tais condutas.

A segunda Lei de Segurança Nacional, ainda sob a égide de Vargas, foi publicada sob o número 1.802, em 5 de janeiro de 1953, e, além de definir crimes contra a "ordem política e social", acresceu em sua ementa também os "crimes contra o Estado". A Lei 1.802/52 tinha para as condutas consideradas mais graves a pena máxima de 30 anos de reclusão. As condutas com esta pena estão elencadas a seguir: submeter o território nacional no todo ou em parte a soberania de Estado estrangeiro ( $\operatorname{art.} 2^{\circ}$, I, da Lei

1.802/53); desmembrar o território nacional (art. $2^{\circ}$, II, da Lei 1.802/53); tentar mudar a ordem política nacional (art. $2^{\circ}$, III, da Lei 1.802/53); matar o Presidente da República, Chefe de Estado Estrangeiro, Vice-Presidente e ministros de Estado, entre outras autoridades (art. 6, “a”, da Lei 1.802/53). Percebe-se que estes crimes também são usualmente considerados políticos para fins de extradição. 
Em março de 1968, o STF julgou um pedido de habeas corpus ${ }^{28}$, com base nesta segunda lei de segurança nacional, seguido de mais quatro pedidos de extensão ${ }^{29}$, e solicitou a soltura de certas pessoas que tinham sido condenadas por crime político apenas por terem seus nomes mencionados em uma caderneta de anotações de Luís Carlos Prestes. O fato destas pessoas estarem presas até o ano de 1968, mostra o efeito prático da condenação por crime político no âmbito interno: silenciam-se ou ao menos, se encarceram as vozes contra o regime por um bom tempo.

Após o término do Estado Novo em 1945, a Lei de Segurança Nacional foi mantida nas Constituições brasileiras que se sucederam. No período do governo militar (19641985), o princípio da segurança nacional iria ganhar importância com a formulação, pela Escola Superior de Guerra, da Doutrina de Segurança Nacional. Destacam-se como seus idealizadores o general Pedro Aurélio de Góis Monteiro, que a formulou quando era ministro da Guerra em 1934, e o general Golbery do Couto e Silva ${ }^{30}$.

A Doutrina de Segurança Nacional, influenciada pelo contexto da Guerra Fria ${ }^{31}$, na qual, o Brasil, como país aliado dos Estados Unidos, tinha por recomendação precípua o combate ao comunismo. Mais do que isso, destaca Cecília Coimbra ${ }^{32}$, altera-se o conceito de "defesa nacional”. Esta, que foi pensada como proteção das fronteiras contra eventuais ataques externos, modifica-se para uma nova doutrina: a luta contra o inimigo principal, as "forças internas de agitação".

De acordo com Daiane Hessmann ${ }^{33}$, a Doutrina de Segurança Nacional, "serviu como a base ideológica do Regime Militar implantado em 1964, e contribuiu para a formação do aparato de informações e de coerção da nova configuração do Estado". Desse modo, o Estado combatia os atos "subversivos", assim considerados os que

28 STF. HC 45060/GB. Paciente João Batista Vilanova Artigas. J. em 1/03/1968. $3^{\mathrm{a}}$ T. <http:www.stf.jus.br>. Acesso em 16/08/2015.

${ }^{29}$ STF. HC 45060/GB. Extensão. $3^{\text {a }}$ T. j. em 18/10/1968. Pacientes: Arlindo Alves Lucena e Eugênio Chemp; STF. HC 45060/GB. Segunda Extensão. J. em 13/09/1968, Paciente: Enio Sandoval Peixoto; STF. HC 45060/GB. Terceira Extensão. Tribunal Pleno. J. em 20/06/1968. Pacientes: Odon Pereira Silva, Francisco Luciano Lepera, Pedro Augusto Azevedo Marques. Disponível em: <http:www.stf.jus.br>. Acesso em 16/08/2015.

${ }^{30}$ FICO, Carlos. Como eles agiam: os subterrâneos da ditadura militar: espionagem e polícia política. Rio de Janeiro: Record, 2001. p. 37

${ }^{31}$ A Guerra Fria, em síntese era polarizada entre Estados Unidos e União Soviética. De um lado, os alinhados com a "democracia": os Estados Unidos e seus aliados; de outro, os comprometidos com o "comunismo internacional": a União Soviética.

${ }^{32}$ COIMBRA, Cecília. "Doutrinas de segurança nacional: banalizando a violência". Psicologia e Estudo, v.5, n. 2, p. 1-22, ano 2000. p. 10.

${ }^{33}$ HESSMANN, Dayane Rúbila Lobo. "Combatendo a 'peste vermelha': A construção do subversivo entre o alto e baixo escalão dos órgãos de repressão durante a Ditadura Militar Brasileira (19641985)". Trabalho apresentado na APUH, Fortaleza, 2009. Disponível em: <http://anpuh.org/anais/wpcontent/uploads/mp/pdf/ANPUH.S25.1042.pdf $\geq$. Acesso em 10.03.2015. 
desobedecessem às premissas do Estado autoritário, sem nenhuma preocupação em desqualificar tais atos como crimes políticos.

No ano de 1967, o então Presidente da República Castello Branco promulgou, através do Decreto-Lei n. 314-67, uma terceira Lei de Segurança Nacional, mais dura que a anterior definindo os "crimes contra a segurança nacional, a ordem política e social" (grifo nosso). Este Decreto-Lei, em consonância com o que determinava o art. 122, $\S \S 1^{\circ}$ e $2^{\circ}$, da Constituição promulgada em 24 de janeiro de 1967, transferiu para a competência da Justiça Militar o processo e julgamento dos crimes políticos tanto realizados por militares como por civis. Esta alteração, além de distorcer os papeis dos tribunais existentes, possibilitou ao governo majorar o rigor contra atos de desaprovação de seu governo, aumentando o número de condenações por crimes políticos ${ }^{34}$.

O governo do general Costa e Silva - período em que foi baixado o Ato Institucional n. 5, de 13 de dezembro de 1968 - foi o auge da linha dura do regime militar. O AI-5 vigorou até dezembro de 1978 e produziu um elenco de ações arbitrárias de efeitos duradouros. Foi referido como sendo "o golpe dentro do golpe"; instituiu a prisão perpétua e a pena de morte e suspendeu o direito a habeas corpus para crimes políticos.

Apesar de suspenso para crimes políticos e eleitorais, o habeas corpus era uma medida judicial bastante utilizada em favor de acusados por crimes políticos, o que obrigava o Estado, a reconhecer oficialmente as prisões efetuadas. Aos juízes, em todas as instâncias, restava a opção de não concederem a ordem de soltura por falta de previsão legal ${ }^{35}$. Apesar disso, o mero pedido de informação em relação à localização do preso e das razões da prisão, eventualmente, geravam como efeito indireto o relaxamento das prisões.

Na sequência, adveio o Decreto-Lei n. 510 de 1969, que alterou dispositivos do Decreto-Lei n. 314/67, agravando certas penas. Entre elas, a do art. 28 que, na redação original do Decreto-Lei n. 314/67 tinha como pena mínima 3 anos e máxima 30 e que passou a ter como pena mínima 12 anos.

\footnotetext{
${ }^{34}$ De acordo com as estatísticas do próprio regime militar houve o aumento de condenações por crimes políticos proporcional ao aumento do rigor das seguintes leis de segurança nacional: Lei 1802/53, DecretoLei 314/67 e Decreto-Lei 869/69. A este respeito, vide o seguinte artigo: BARCELLOS, Daniela Silva Fontoura e SGANZERLA, Rogério. "Direitos restritos e pena de morte: os processos de crimes políticos no superior tribunal militar entre 1964 a 1975'. Trabalho apresentado no XXIV Encontro Nacional do CONPEDI, realizado na Universidade Federal de Sergipe - UFS. Disponível em: $<$ http://www.conpedi.org.br >. Acesso agosto 2015.

35 A este respeito vide os seguintes julgados do STF: HC 49976 e HC 47125. Disponível em: <http:www.stf.jus.br>. Acesso agosto 2015.
} 
No mesmo ano de 1969, o governo militar optou por criar a quarta Lei de Segurança Nacional, através do Decreto-Lei n. 898, de 29 de setembro de 1969, assinado por Augusto Rademaker Grünewald, Aurélio de Lira Tavares e Márcio de Sousa Melo, todos integrantes da Junta Governativa Provisória de 1969. O Decreto-Lei 898/69 manteve o conceito de segurança nacional (art. 3º, caput, do DL 898/69), que abrangia a preservação da segurança externa e interna (art. $3^{\circ}, \S^{\circ}$, do DL 898/69), inclusive a prevenção e repressão da guerra psicológica adversa e (art. $3^{\circ}, \S 2^{\circ}$, do DL 898/69) da guerra revolucionária ou subversiva (art. $3^{\circ}, \S 3^{\circ}$, do DL 898/69). Além disso, esta lei ampliou o seu alcance, para incluir crimes cometidos no todo ou em parte em território nacional, ou que nele, embora parcialmente, produziram ou deviam produzir o seu resultado (art. $4^{\text {o }}$ do DL 898/69); crimes cometidos no estrangeiro e que, mesmo parcialmente, produziram ou deviam produzir seu resultado no território nacional (art. $5^{\circ}$ do DL 898/69) e os crimes cometidos por estrangeiro contra brasileiro fora do Brasil, (art. $6^{\circ}$ do DL 898/69), sempre ressalvadas as disposições de convenções, tratados e regras de Direito Internacional. Neste decreto, as penas foram agravadas admitindo-se prisão perpétua e a pena de morte.

A quinta lei de segurança nacional, Lei n. 6.620/78, também tinha como escopo a preservação da segurança externa e interna, inclusive a prevenção e repressão da guerra psicológica adversa e da guerra revolucionária ou subversiva. Assim, definia nos parágrafos do referido artigo segurança interna ${ }^{36}$, guerra psicológica ${ }^{37}$ e guerra revolucionária ${ }^{38}$. Nesta lei, a greve era indiretamente proibida pelos arts. 27,35 e 37 que tipificavam como crime dificultar o funcionamento dos serviços públicos ou atividades essenciais administradas pelo Estado, prestados diretamente pelo estado ou por particulares, mediante concessão autorização ou permissão. Esta lei, mais branda comparada à anterior, aboliu a pena de prisão perpétua e a pena de morte, embora ainda tenha mantido o julgamento de civis por militares.

\footnotetext{
36 “A segurança interna, integrada na segurança nacional, corresponde às ameaças ou pressões antagônicas, de qualquer origem, forma ou natureza, que se manifestem ou produzam efeito no país". (art. $3^{\circ}, \S^{\circ}$ da Lei n. $6.620 / 78$ )

37 “A guerra psicológica adversa é o emprego da propaganda, da contrapropaganda e de ações nos campos políticos, econômico, psicossocial e militar, com a finalidade de influenciar ou provocar opiniões, emoções, atitudes e comportamentos de grupos estrangeiros, inimigos, neutros ou amigos, contra a consecução dos objetivos nacionais". (art. $3^{\circ}, \S 2^{\circ}$ da Lei n. 6.620/78)

$38 \S 3^{\circ}$ - A guerra revolucionária é o conflito interno, geralmente inspirado em uma ideologia, ou auxiliado do exterior, que vise à conquista subversiva do poder pelo controle progressivo da Nação. (art. $3^{\circ}, \S 3^{\circ}$ da Lei n. 6.620/78)
} 
Durante o início da abertura política foi promulgada a sexta e última Lei de Segurança Nacional, a Lei n. 7.170, de 14 de dezembro de 1983. A Lei n. 7.170/83, ainda em vigor, "define crimes contra segurança nacional, a ordem política e social, estabelece seu processos e julgamento e dá outras providências”. Esta lei exige para a configuração de crime político a aferição da motivação e dos objetivos políticos do agente, mas também a lesão real ou potencial dos seguintes bens jurídicos: integridade territorial e soberania nacional, regime representativo e democrático, a federação, o estado de direito e a pessoa dos chefes dos poderes da união (art. $1^{\circ}$ da Lei 7.170/83). Com base neste parâmetro, foi decidido o HC 73.451/RJ em que o extravio de armamento militar fabricado para exportação com permissão da autoridade federal não configura crime político pela inexistência do elemento subjetivo consubstanciado na motivação. Assim, profere o Ministro Mauricio Corrêa em sua ementa:

Crime político: configura-se somente quando presentes os pressupostos cristalizados no art. $2^{\circ}$ da Lei $n^{\circ} 7.170 / 83$ : a motivação política e a lesão real ou potencial aos bens juridicamente tutelados. (BRASIL. STF. HC 73451/RJ. $2^{a}$ T. Rel. Min, Maurício Correa. J em 08/04/1997. Deferido por unanimidade)

Outro caso interessante é a análise de pedido de habeas corpus solicitado em favor de José Lima Azevedo angolano, com nacionalidade portuguesa, ex-estudante da Faculdade de Economia do Porto, que se encontrava preso administrativamente no Brasil para fins de expulsão, desde 23/11/1964. O paciente pertencente ao MPLA - Movimento Pro Libertação de Angola - entidade política, sem existência regular no país, foi acusado por porte de armas, tráfico de armas e propaganda subversiva. Caso fosse expulso, o paciente corria o risco de ser entregue a Portugal, onde era acusado de crimes políticos, o que seria uma decisão inaceitável, uma vez o "que nossa lei não admite, na mesma linha dos acordos internacionais firmados pelo Brasil (art. 2, VIII, do DL 394/38)”. A saída preferida pelo STF foi negar a ordem, mantendo o paciente preso a fim de evitar sua expulsão como uma espécie de extradição indesejada.

Expulsão. Nocividade. Extradição indireta. 1) o julgamento da nocividade do estrangeiro pertence ao executivo. 2) o expulsando não pode ser entregue as autoridades do pais, onde e acusado de atividade subversiva, porque isso equivaleria a extradição indireta, não solicitada e por crime político. Garantias do executivo em tal sentido. (BRASIL. STF. 
HC 41913, Rel. Min. Victor Nunes Leal, Tribunal Pleno, j. em 17/03/1965.)

Observa-se que, de uma lei de segurança nacional já bastante repressora, criada na Era Vargas, em que cinco crimes tinham pena máxima de 30 anos de reclusão, passamos para o Decreto-Lei 314/67 que alterou a competência dos crimes políticos para a Justiça Militar, seguido do Decreto-Lei n. 898/69 que aumentou para dezesseis situações com pena máxima (sendo esta a pena de morte). Em síntese, houve um recrudescimento progressivo do tratamento ao crime político durante os períodos autoritários. Na preparação para a abertura política, promulga-se nova lei de n. 7.170/83 que diminuiu um pouco os abusos do auge da linha dura, extinguindo a prisão perpétua e a pena de morte, reestabelecendo até mesmo o direito ao habeas corpus. Como foi visto, por meio da Lei de Segurança Nacional, os regimes autoritários conseguiram implementar mecanismos oficiais para realizar legalmente uma forte repressão, sem problema em qualificar as condutas de resistência, consideradas "subversivas" como crimes políticos.

\subsection{A Anistia e o Reconhecimento do Crime Político Bilateral}

A Lei de Anistia, Lei n. 6.683 de 28 de agosto de 1979, abrange sob a concepção de crimes políticos "tanto para os crimes praticados por agentes políticos em nome da ditadura, quanto aqueles praticados pelos que combateram o regime ${ }^{39}$ ". Ademais, inclui sob sua proteção tanto os crimes políticos quanto os conexos com estes (art. $1^{\circ}$ da Lei 6.683/79).

Cabe ressaltar que a prática de anistiar crimes políticos com extensão aos crimes conexos já tinha sido realizada no Brasil em outros contextos históricos. O Decreto n. 3.102 de 13 de janeiro de 1916, o Decreto 19.395 de 6 de novembro de 1930 e o Decretolei n. 7.474 de 18 de abril de 1945 já haviam dado anistia aos crimes políticos, sempre a estendendo aos crimes comuns, desde que conexos aos crimes políticos.

Este foi o entendimento do STF, no Recurso de Habeas Corpus $59834^{40}$ relatado pelo Ministro Firmino Paz em que se analisou se o paciente, ex-militar, deveria ser libertado, mediante a lei de anistia pois, embora anistiado pelos crimes políticos, tinha

\footnotetext{
39 MEYER, Emílio Peluso Neder. Ditadura e responsabilização: elementos para uma justiça de transição no Brasil. Belo Horizonte: Arraes, 2012. p. 125.

${ }^{40}$ BRASIL. STF. $2^{\text {a }}$ T. RHC 59834, Rel. Min. FIRMINO PAZ, j. em 04/05/1982. Disponível em: <http:www.stf.jus.br>. Acesso em 15/06/2015.
} 
também sido condenado pelo crime militar de deserção. O caso acabou sendo julgado em favor do paciente, por entender que a deserção era conexa ao crime político.

Entretanto, deve ficar claro que o conceito de conexão utilizado pela lei de segurança nestes casos não corresponde ao conceito de conexão do direito penal expressos em nossos Códigos Penal e de Processo Penal. A ADPF $153^{41}$ proposta em 21 de outubro de 2008 pelo Conselho Federal da OAB, tendo como advogado Fábio Konder Comparato, colocou à prova o entendimento da corte suprema a respeito do conceito de crime político ao buscar a inconstitucionalidade da Lei da Anistia no que tange à conduta dos agentes do Estado.

Neste julgamento, o Supremo confirmou o entendimento da Lei da Anistia, considerando-a constitucional, ao mesmo tempo em que assentou a definição de crime político não apenas como atos de resistência, mas também abrangendo os atos praticados pelos agentes do próprio Estado na defesa do regime. É o que se lê na ementa, in verbis:

(...) Conceito e definição de "crime político" pela Lei n. 6.683/79. São crimes conexos aos crimes políticos "os crimes de qualquer natureza relacionados com os crimes políticos ou praticados por motivação política"; podem ser de "qualquer natureza", mas [i] hão de terem estado relacionados com os crimes políticos ou [ii] hão de terem sido praticados por motivação política; são crimes outros que não políticos; são crimes comuns, porém [i] relacionados com os crimes políticos ou [ii] praticados por motivação política. A expressão crimes conexos a crimes políticos conota sentido a ser sindicado no momento histórico da sanção da lei. A chamada Lei de anistia diz com uma conexão sui generis, própria ao momento histórico da transição para a democracia. Ignora, no contexto da Lei n. 6.683/79, o sentido ou os sentidos correntes, na doutrina, da chamada conexão criminal; refere o que "se procurou", segundo a inicial, vale dizer, estender a anistia criminal de natureza política aos agentes do Estado encarregados da repressão. 4. A lei estendeu a conexão aos crimes praticados pelos agentes do Estado contra os que lutavam contra o Estado de exceção; daí o caráter bilateral da anistia, ampla e geral, que somente não foi irrestrita porque não abrangia os já condenados --- e com sentença transitada em julgado, qual o Supremo assentou --- pela prática de crimes de terrorismo, assalto, seqüestro e atentado pessoal. (BRASIL. STF. ADPF n. 152/DF. Tribunal Pleno. Rel. Min Eros Grau. j. em 29/04/2010. Disponível em: <http:www.stf.jus.br>. Acesso em 16/08/2015)

Assim, a já fluida caracterização de crime político vem ampliar ainda mais seu espectro de aplicação, prestando-se aos mais diversos papeis.

\footnotetext{
${ }^{41}$ BRASIL. STF. ADPF n. 152/DF. Tribunal Pleno. Rel. Min Eros Grau. j. em 29/04/2010. Disponível em: <http:www.stf.jus.br>. Acesso em 16/08/2015.
} 


\section{CONCLUSÃO}

O emprego da expressão de crime político vem servindo ao longo da história do ordenamento jurídico brasileiro para propósitos antagônicos: tornar mais rigorosa as penas contra atos considerados "subversivos" por ameaçarem a ordem interna, ao mesmo tempo em que possibilitam ao Brasil abrigar estrangeiros que realizam atos de resistência contra arbítrios de outros Estados estrangeiros com governo ditatorial e/ou autoritário.

Neste sentido, o pedido de extradição funda-se usualmente em dois argumentos. O primeiro é que os atos realizados em seu território não configuraram crime político, mas sim crime comum. O segundo, utilizado para situações extremas, é alegação de que os agentes não merecem asilo porque, dada a gravidade da conduta praticada, as ações são, de fato, atos terroristas.

Entre os últimos julgados célebres envolvendo o tema, estão o processo de extradição de Cesare Battisti e a ADPF 153, ambos julgados pelo STF. Nestes casos, estava em jogo, respectivamente, entre outras disputas, a linha divisória entre crime comum e político e a possibilidade ou não do delito político ser cometido por autoridade estatal.

De acordo com Gilmar Mendes, a atrocidade que pode servir para não impedir a extradição de um agente estrangeiro é ignorada quando se trata de punibilidade de agentes nacionais. Para o Ministro, há diferenças entre o tratamento do crime político na democracia e na ditadura:

(...) havendo ditadura, a possiblidade do crime político existe. Reconhecese aos cidadãos o direito de defesa contra a tirania. Nesse caso, o revolucionário é uma vítima como toda a sociedade e não tendo meios jurídicos par se proteger, lança mão do recurso que lhe sobre, que é sua atuação contra os seus opressores. Nessas situações, o crime pode ser considerado um ato político em defesa do próprio agente ou da sociedade. (...) assim o mesmo crime que, numa ditadura pode vir a ser absolvido sob a forma de anistia, numa democracia é crime mesmo, crime preponderantemente comum, anda que a motivação interior tenha origem numa hostilidade política ${ }^{42}$.

42 BRASIL. STF. Extradição 1085. Rel Cézar Peluso. J. em 16/12/2009. Disponível em: <http:www.stf.jus.br>. Acesso em 16/08/2015. 
Portanto, a disputa pelo significado da expressão crime político continua viva no ordenamento jurídico nacional e, como visto, tem dupla função. O seu significado passa pela relação com o crime comum, com os crimes conexos e com o ato terrorista. O estabelecimento dessas fronteiras serve a propósitos diversos e até mesmo antagônicos: o aumento do rigor do julgamento do crime, anistiar, conceder asilo ou extraditar. O embate continua nas decisões do Supremo Tribunal Federal, que, eventualmente, enfrenta até mesmo a oposição de cortes internacionais.

\section{REFERÊNCIAS BIBLIOGRÁFICAS}

ACCIOLY, Hildebrando. Manual de Direito Internacional Público. 6. ed. São Paulo: Saraiva: 1964.

ARAÚJO, Luiz Alberto David; PRADO, Luiz Régis. Alguns Aspectos das Limitações ao Direito de Extraditar. Revista de Informação Legislativa, Brasília, v. 19, n. 76, outubro/dezembro $1992, \quad$ p. $79 . \quad$ Disponível em <http://www2.senado.gov.br/bdsf/item/id/181392>. Acesso em agosto 2015.

BARCELLOS, Daniela Silva Fontoura e SGANZERLA, Rogério. "Direitos restritos e pena de morte: os processos de crimes políticos no superior tribunal militar entre

1964 a 1975'. Trabalho apresentado no XXIV Encontro Nacional do CONPEDI, realizado na Universidade Federal de Sergipe - UFS. Disponível em: www.conpedi.org.br. Acesso em $1 / 08 / 2015$.

BARROSO, Luís Roberto; TIBÚRCIO, Carmen. Direito Constitucional Internacional. Rio de Janeiro: Renovar, 2013.

FERREIRA, Norma Sandra de Almeida. As pesquisas denominadas "estado da arte". Educação \& Sociedade, 2002, Vol.23, p.257-272.

FRANCO, Alberto Silva. Crimes Hediondos: notas sobre a Lei 8072/90. 3. ed. São Paulo: Revista dos Tribunais, 1994.

GOMES, Érica Xavier Moura. A Extradição e o Crime Político. Monografia de Conclusão de Curso de Direito. Rio de Janeiro: UFRJ, 2010, p. 53.

GORAIEB, Elizabeth. A Extradição no Direito Brasileiro. Rio de Janeiro: Mauad, 1981. 
GUIMARÃES, Marcelo Ovídio Lopes. Tratamento Penal do Terrorismo. São Paulo: QuartierLatin, 2007. p. 63-64.

INSTITUT DE DROIT INTERNATIONAL.Justitiaet Pace. Résolutionsd'Oxford (Extradition). Session d'Oxford, 9 Septembre 1880. Rapporteurs MM. Ludwig von Bar, Charles Brocher, Louis Renault et Caspar Bluntschli e Révision des articles 13 et 14 des Résolutionsd'Oxford (Extradition). Session de Genève, 8Septembre 1892. Rapporteurs MM. Albéric Rolin et Heinrich Lammasch. Disponível em <http://www.idiiil.org/>, acesso em agosto de 2015.

JIMÉNEZ DE ASÚA, Luis. Tratado de Derecho Penal. 5. ed. Buenos Aires: Editorial Losada, s/a. t. III. p. 185.

LAUTERPACHT, Hersch. Laws of nations and the punishment of war crimes.British Yearbook of International Law, n. 58, 1944.

LUPI, André Lipp Pinto Basto. O problema do depositário infiel persiste: reflexões acerca da interpretação do art. $5^{\circ}, \S 3^{\circ}$ da Constituição Federal. In: BORGES, Paulo; FERREIRA JÚNIOR, Lier Pires (coord.). Direitos Humanos e Direito Internacional. Curitiba: Juruá, 2006.

MEYER, Emílio Peluso Neder. Ditadura e responsabilização: elementos para uma justiça de transição no Brasil. Belo Horizonte: Arraes, 2012.

PRADO, Luiz Régis; CARVALHO, Érika. Delito Político e Terrorismo: uma aproximação conceitual. Revista dos Tribunais, n. 771, Doutrina Penal, Primeira Seção, janeiro de 2007.

RUSSOMANO, Gilda Maciel Corrêa Meyer. A Extradição no Direito Internacional e no Direito Brasileiro. 3. ed. São Paulo: Revista dos Tribunais, 1981.

TENÓRIO, Oscar. Direito Internacional Privado. 11 ed. V. II. Rio de Janeiro: Freitas Bastos, 1976. 